\title{
LITHUANIA - BELARUS ECONOMIC RELATIONS: HOW THE EU ACCESSION IMPACTED BILATERAL TRADE
}

\author{
Romualdas Ginevičius ${ }^{1}$, Manuela Tvaronavičienė², \\ Renata Korsakiené $\dot{e}^{3}$, Kristina KalaDinskaité ${ }^{4}$ \\ Vilnius Gediminas Technical University, Sauletekio al. 11, LT-10223 Vilnius, Lithuania \\ E-mail: ${ }^{1}$ romualdas.ginevicius@adm.vtu.lt; ${ }^{2}$ manuela@vv.vtu.lt; \\ ${ }^{3}$ renatakorsa@takas.lt; ${ }^{4}$ kristina.kalasinskaite@vv.vtu.lt
}

Received 5 December 2006; accepted 5 February 2007

\begin{abstract}
Lithuania among other 10 Central and Eastern European countries joined the European Union on 1 May 2004. A lot of forecasts about transformations in international trade relationships had been discussed; overall shift towards the EU had been expected. The paper aims to verify what actual effect newly imposed trade regulations have. Presented elaboration of discussed issue would be performed in the following sequence. At first, trade structure by product groups of trade between Lithuania and Belarus in the years 2000 and 2005 would be juxtaposed. Volumes of import and export would be considered respectively. Changes in trade regime would be taken into account. Adopted approach allowed us to trace which changes in trade regime impacted trade character and which not.
\end{abstract}

Keywords: relative weights, GDP, exports, imports, trade regime.

\section{Introduction}

Trade in Lithuania developed to a remarkable extent in the 1990s. This increase was influenced by such processes as transition to market economy, gradual integration into the EU market (Association Agreement signed bilaterally), FDI inflows, etc. Traditionally the most active trade is observed between Lithuania and the neighbouring countries. Belarus bordering Lithuania to the east historically has developed tight economic relations. A glance at statistical data verifies that importance of Belarus as trading partner during the latest years can not be straightforwardly viewed as diminishing (Figs 1, 2, 3) despite the changed trade conditions. Lithuania together with other nine Central and Eastern European countries joined the EU on 1 May 2004. The accession process was followed by the adoption of the EU common trade policy which includes all trade agreements concluded between the EU and third countries by that day. Hence the new trade regime with Belarus is seen as the one of the reasons causing changes in trade relations. A vast literature considering factors impacting changes in trade between new member states and ones belonging to another trading blocks could be found (Zghini, 2005; Hamilton, 2005; Tvaronavičiene, Tvaronavičius, 2005; Salinas, Aksoy, 2006; Tarr, Navaretti, 2005).

This paper aims to contribute to recent elaborations by focusing on actual effects the EU trade policy has had on the Lithuanian-Byelorussian trade. We are going to comment on export and import trends between Lithuania and Belarus before and after accession. In our further analysis we will take a closer look at trade in main product groups in order to trace impact of new trade regime on composition of import and export by major product groups. Scrutinizing of exports and imports of manufactured products is supposed to be a major tool allowing us to indicate which items of trade displayed sensitivity to newly imposed trade conditions.

\section{Lithuanian export and import trends with Belarus}

A glance at Lithuanian-Byelorussian export-import tendencies recorded before and after Lithuanian ac- 
cession reveals steady growth of Lithuanian export to Belarus and uneven development of Lithuanian imports from Belarus (Fig 1). Notably, the rise of exports to Belarus was gradual throughout the years 2001-2005. Imports from Belarus grew especially significantly during the pre-accession year $(128 \%)$, later dropped significantly. A closer look at Lithuanian-Belarus trade by product groups indicates that the recorded growth of imports was achieved mainly on account of mineral products (297\%), wood and articles of wood $(123 \%)$; prepared foodstuffs; beverages, spirits and vinegar; tobacco (111\%) (Table 1). In contrast, gradual growth of exports took place mainly due to trade in products of agriculture (88\%), wood and articles of wood $(80 \%)$, prepared foodstuffs; beverages, spirits and vinegar; tobacco (63\%), products of the chemical or allied industries $(40 \%)$, textiles and textile articles (40\%) (Table 1). The transition to the EU foreign trade regime had no significant impact on exports to Belarus and the rise of exports to Belarus remained steady throughout 2005 $(20 \%)$. However the analysis of available figures by product groups revealed the decrease in exports of mineral products $(-68 \%)$, agriculture products $(-12 \%)$; wood and articles of wood $(-8 \%)$ (Table 1). Notably the growth of exports was achieved mainly in textiles and textile articles (55\%), the manufacture of skilled-labour-intensive products $(51 \%)$ and other products $(67 \%)$ (Table 1$)$.

To sum up, an increase of overall level of import tariffs applied to third countries, caused a decrease of imports from Belarus ( $-32 \%)$. The decrease was especially significant in trade of mineral products $(-50 \%)$. Imports of such product groups as wood and articles of wood (18\%); prepared foodstuffs; bever-

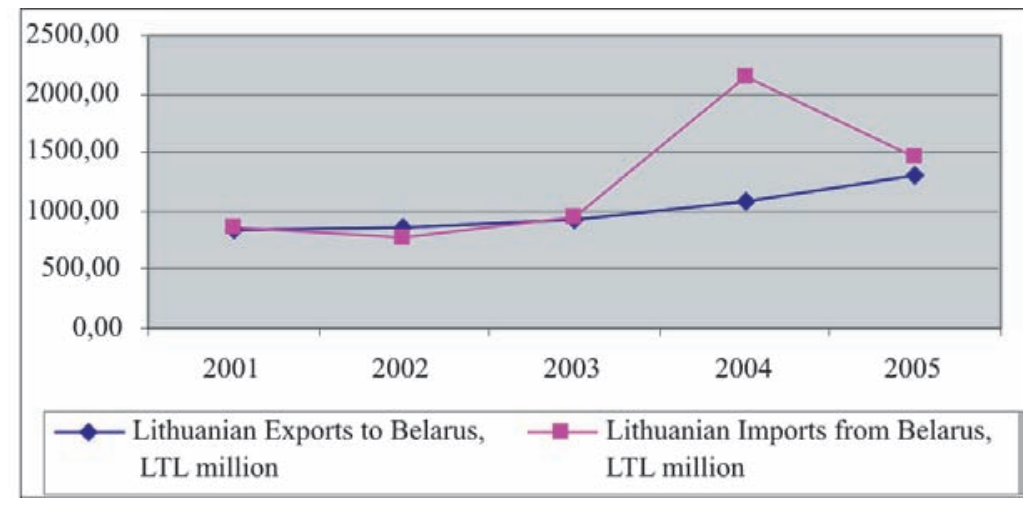

Source: The Customs Department under the Ministry of Finance of the Republic of Lithuania

Fig 1. Lithuanian Exports and Imports with Belarus, 2001-2005 (LTL mill.)
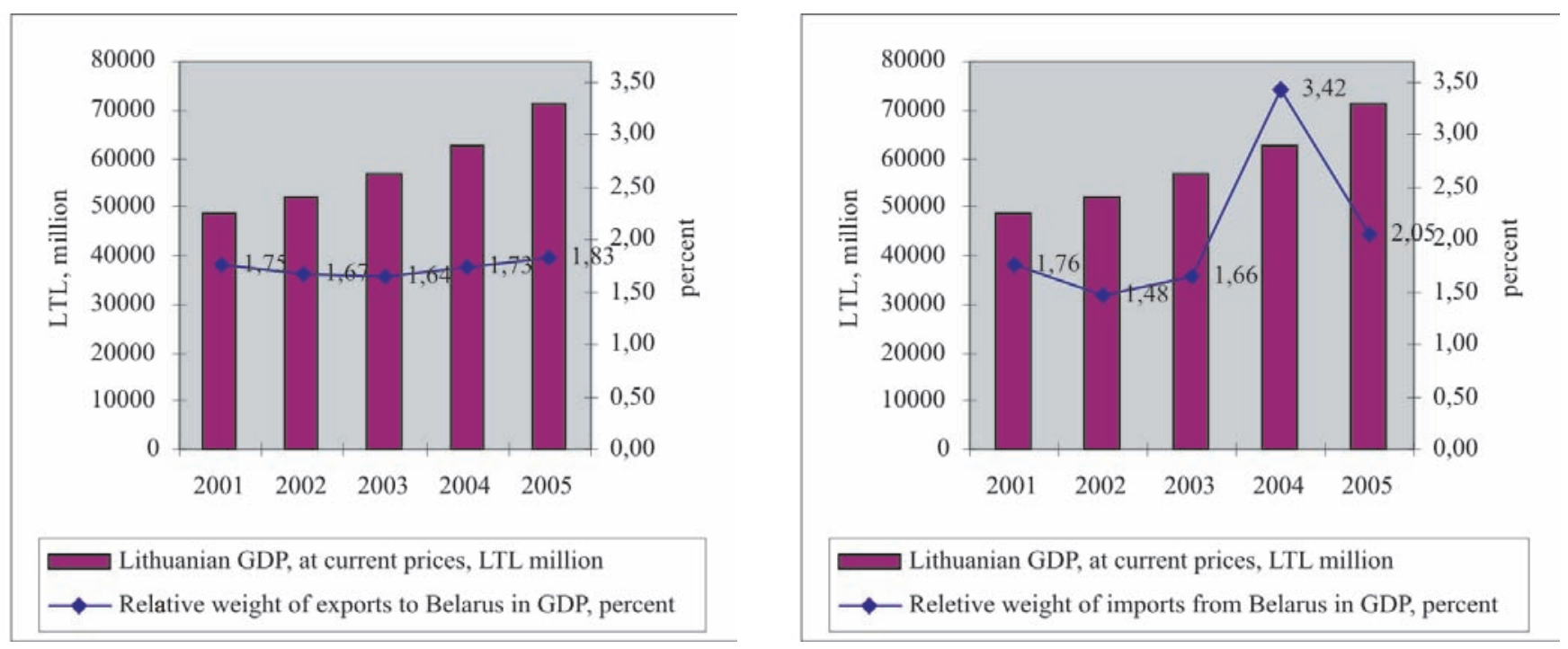

Source of GDP dates: Balance of Payments of the Republic of Lithuania of 2005

Fig 2. Change of relative weights in GDP (of Belarus exports)

Fig 3. Change of relative weights in GDP (of Belarus imports) 


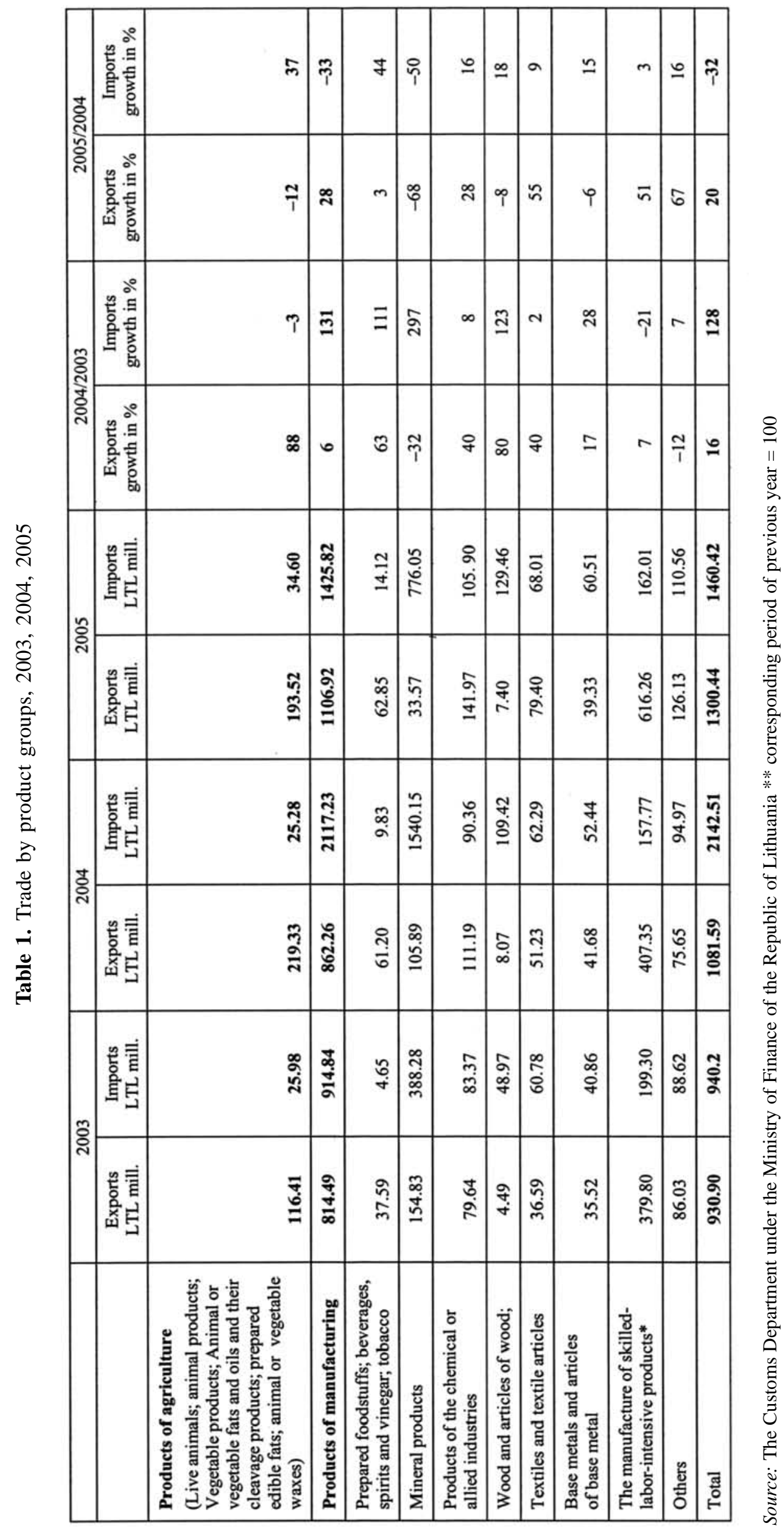


ages, spirits and vinegar; tobacco (44\%) dropped significantly as well (Table 1).

Absolute Lithuanian-Byelorussian trade data indicating volumes of goods traded does not provide actual tendencies if growth of Lithuania's Gross Domestic Product (GDP) is not being taken into account. The clear rationale lies behind: if trade is developing its share or relative weight in GDP grows as well, and vice versa, respectively. Judging from the recent statistical data Lithuania's GDP has been growing since 2001 (Figs 1, 2). Exports to Belarus, growing in absolute figures, decreased slightly after accession but later the gradual growth recovered. Imports, expressed in terms relative to GDP replicated the already traced tendency. In 2004, the relative weights of imports rose in Lithuania's GDP up to $3,42 \%$, which was the highest share achieved in the five-year period (Fig 3). In 2005 this rate dropped to $2,05 \%$ and was slightly higher than in 2003. Hence, we can conclude that accession impacted import from Belarus rather significantly.

Another measure of foreign trade tendencies is juxtaposing of import and export change tendencies to trade tendencies with a particular country. Data on Lithuania's exports verifies that during the last five years exports have grown steadily (Fig 4). However during the same period the relative weights of exports to Belarus in total Lithuanian exports were declining every year. The situation allows concluding that Lithuania switched its exports from Belarus. The fact that change of relative weights of exports to Belarus did not appear in figures of export to Belarus, estimated as a share of GDP, leads us to the following corollary. Lithuanian export expanded but it shifted to other, most likely, European countries. Relative decrease of exports to Belarus was neutralized by general expansion of exports (compared to GDP growth). As a result, absolute volume of exports to Belarus increased but, in principal, export to Belarus started gradually to lose its economic importance.

As concerns Lithuanian import from Belarus calculated as a share of total imports (Fig 5), it emulates tendencies of that calculated as import to GDP (Fig 3). It provides additional consistent evidences about declining significance of Belarus as trading partner, i.e. we can claim that change of foreign trade regime with third countries after the EU accession had direct impact on Lithuania's import rates from Belarus.

In our analysis we tackle foreign trade of industrial and agricultural sectors. This approach is natural as latter sectors, as a rule, comprise a major share of international trade. Before we switch to even more detailed analysis of industrial and agricultural sectors let us just take a short glance at changes in export and import of Lithuanian services before and after the EU accession.. Relative weight of export to Belarus in total exports of Lithuanian services decreased from $10,06 \%$ in 2004 to $7,35 \%$ in 2005 (Table 2). Respectively, import of services from Belarus decreased from 7,57\% in 2004 to 5,68 \% in 2005 (Table 2). To generalize, despite the trade in services was not so significant neither before nor after accession, decreasing tendencies are being found as characteristic for this sector as well.
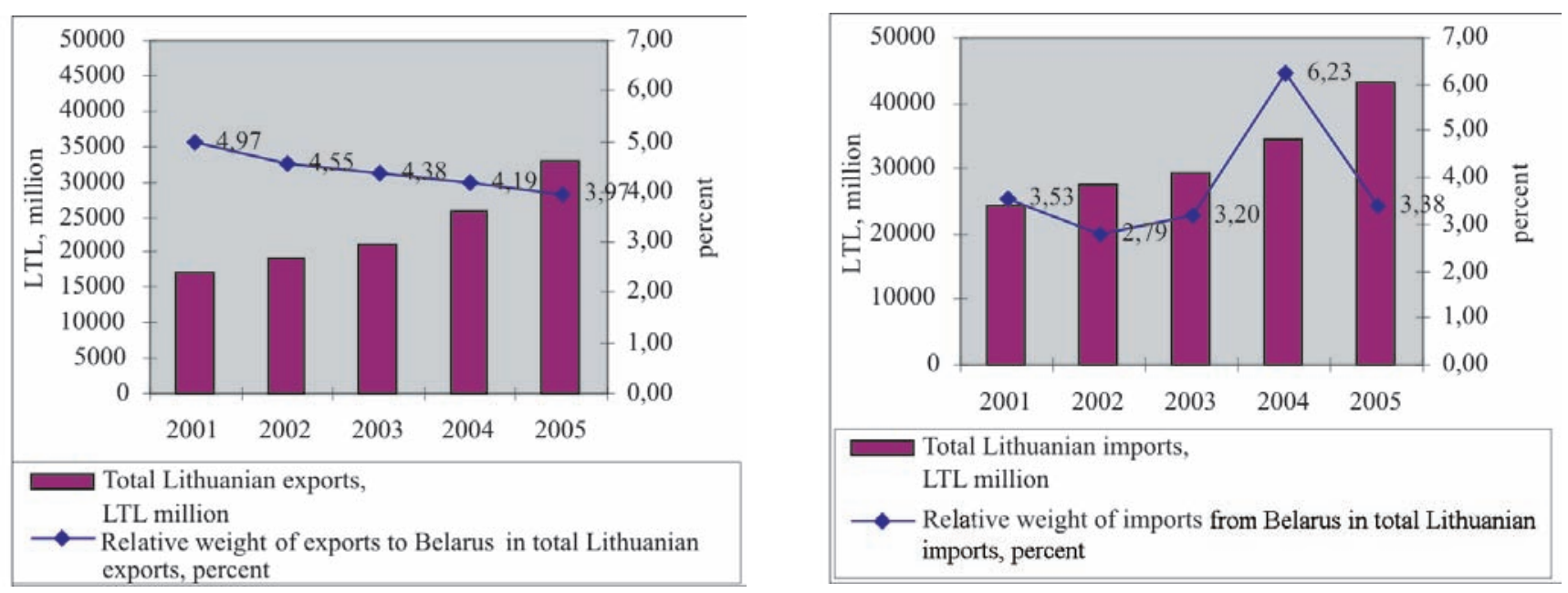

Source of Lithuanian Total exports and imports dates: Balance of Payments of the Republic of Lithuania of 2005

Fig 4. Change of relative weights in total Lithuanian exports
Fig 5. Change of relative weights in total Lithuanian imports 
Table 2. Trade of Lithuanian services, 2004, 2005

\begin{tabular}{|l|c|c|c|c|}
\hline & \multicolumn{2}{|c|}{2004} & \multicolumn{2}{c|}{2005} \\
\hline & $\begin{array}{c}\text { Export } \\
\text { LTL } \\
\text { mill. }\end{array}$ & $\begin{array}{c}\text { Import } \\
\text { LTL mill. }\end{array}$ & $\begin{array}{c}\text { Export } \\
\text { LTL mill. }\end{array}$ & $\begin{array}{c}\text { Import } \\
\text { LTL mill. }\end{array}$ \\
\hline $\begin{array}{l}\text { Total Lithuanian } \\
\text { services, LTL } \\
\text { million }\end{array}$ & 6797.63 & 4534.74 & 8641.42 & 5715.36 \\
\hline of which: & & & & \\
\hline $\begin{array}{l}\text { Belarus, LTL } \\
\text { million }\end{array}$ & 683.96 & 343.39 & 634.79 & 324.37 \\
\hline $\begin{array}{l}\text { Relative weight in } \\
\text { total Lithuanian } \\
\text { services, \% }\end{array}$ & $\mathbf{1 0 . 0 6}$ & $\mathbf{7 . 5 7}$ & $\mathbf{7 . 3 5}$ & $\mathbf{5 . 6 8}$ \\
\hline
\end{tabular}

\section{Impact of new trade regime on composition of Lithuanian-Byelorussian bilateral trade}

The available figures on trade between Lithuania and Belarus indicate that in the structure of exports products of manufacturing dominate (Fig 6). Lithuania's entry into EU influenced the structure of goods in trade with Belarus. Hence, export of manufactured goods grew by $5 \%$ in 2005. Anyway Lithuanian exporters were facing full customs duties as well as the quota structure in the agricultural sector. Hence volume of agricultural products fell by $5 \%$ in 2005 .

In 2004 in the structure of Lithuanian exports to Belarus skilled-labour-intensive products (38\%), products of the chemical or allied industries $(10 \%)$ and mineral products $(10 \%)$ dominated (Table 3 ). Notably, in 2005 the share of skilled-labour-intensive products in Lithuanian-Belarus exports increased by $47 \%$ (Table 3).

To generalize, Lithuanian exporters treat Belarus as an attractive market for skilled-labour-intensive products. Growth of exports of this product group has been observed since 2001. However, the importance of mineral products in the structure of exports to Belarus is diminishing. After steadily growth till the year 2003 a sharp decrease of export of this product group is observed (Fig 7). Notably, the share of agricultural products in total imports from Belarus is seen as minor and decreasing (Fig 8).

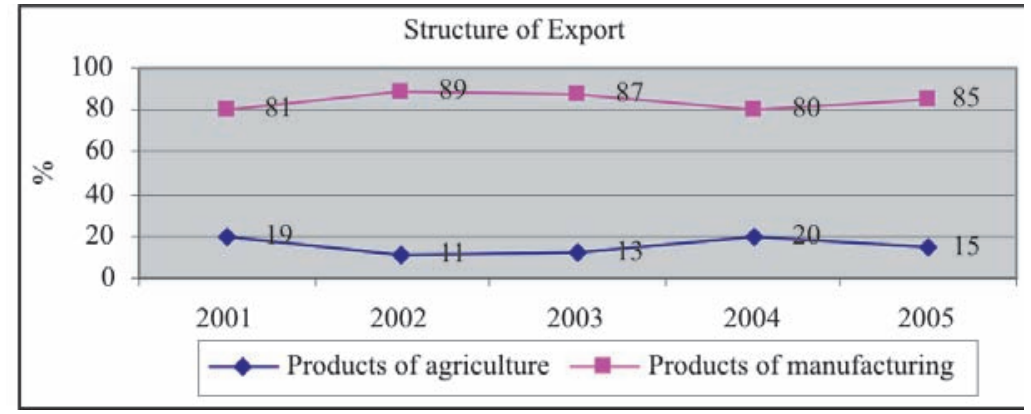

Source: The Customs Department under the Ministry of Finance of the Republic of Lithuania

Fig 6. Structure of Exports to Belarus

Table 3. Structure of Lithuanian exports to Belarus

\begin{tabular}{|c|c|c|c|c|c|}
\hline & 2001 & 2002 & 2003 & 2004 & 2005 \\
\hline & $\%$ & $\%$ & $\%$ & $\%$ & $\%$ \\
\hline Lithuanian Exports to Belarus & 100 & 100 & 100 & 100 & 100 \\
\hline $\begin{array}{l}\text { Products of agriculture } \\
\text { (Live animals; animal products; Vegetable products; Animal or vegetable } \\
\text { fats and oils and their cleavage products; prepared edible fats; animal or } \\
\text { vegetable waxes) }\end{array}$ & 19 & 11 & 13 & 20 & 15 \\
\hline Products of manufacturing & 81 & 89 & 87 & 80 & 85 \\
\hline Prepared foodstuffs; beverages, spirits and vinegar; tobacco & 6 & 5 & 4 & 6 & 5 \\
\hline Mineral products & 10 & 15 & 17 & 10 & 3 \\
\hline Products of the chemical or allied industries & 8 & 10 & 9 & 10 & 11 \\
\hline Wood and articles of wood; & 0 & 1 & 0 & 1 & 1 \\
\hline Textiles and textile articles & 4 & 4 & 4 & 5 & 6 \\
\hline Base metals and articles of base metal & 4 & 4 & 4 & 4 & 3 \\
\hline The manufacture of skilled-labour-intensive products* & 37 & 39 & 41 & 38 & 47 \\
\hline Others & 12 & 12 & 9 & 7 & 10 \\
\hline
\end{tabular}

* Machinery and mechanical appliances; electrical equipment; Vehicles, aircraft, vessels and associated transport equipment; Optical, photographic, cinematographic, measuring, checking, precision, medical or surgical instruments and apparatus; clocks and watches; musical instruments

Source: The Customs Department under the Ministry of Finance of the Republic of Lithuania 


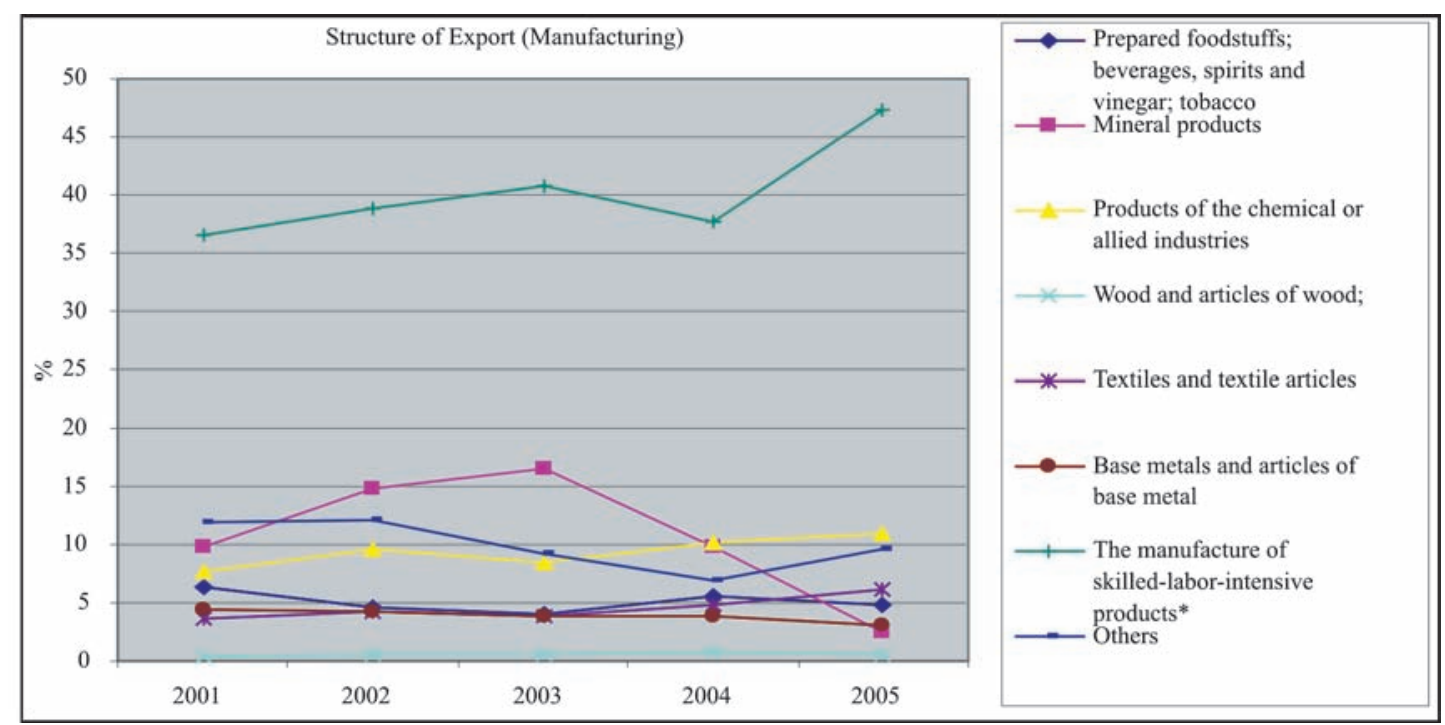

Fig 7. Structure of Exports (Manufacturing) to Belarus

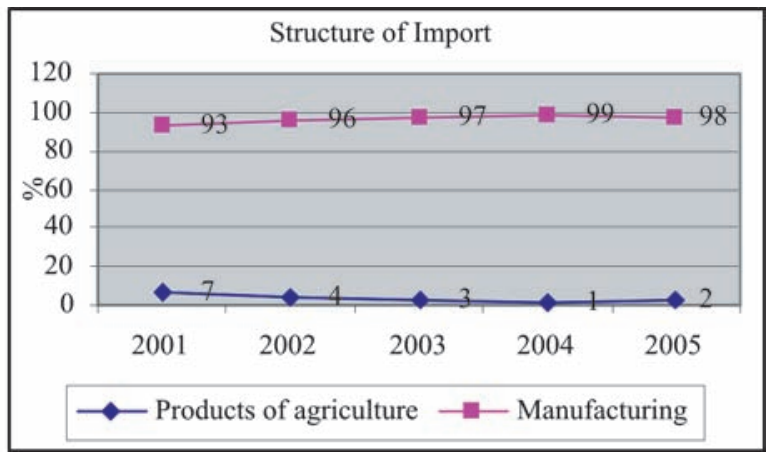

Fig 8. Structure of Imports
In 2004 in the structure of imports from Belarus mineral products $(72 \%)$ dominated with a minor share of other product groups (Table 4). However, the change of trade regime diminished the imports of mineral products by $53 \%$.

To generalize, in the structure of imports from Belarus mineral products take the major share. The fast increase of this share witnessed from the year 2002 was followed by a sharp decrease after adoption of new trade regime (Fig 9). The import of skilled-la-

Table 4. Structure of Lithuanian imports from Belarus

\begin{tabular}{|c|c|c|c|c|c|}
\hline & 2001 & 2002 & 2003 & 2004 & 2005 \\
\hline & $\%$ & $\%$ & $\%$ & $\%$ & $\%$ \\
\hline Lithuanian Imports from Belarus & 100 & 100 & 100 & 100 & 100 \\
\hline $\begin{array}{l}\text { Products of agriculture } \\
\text { (Live animals; animal products; Vegetable products; Animal } \\
\text { or vegetable fats and oils and their cleavage products; } \\
\text { prepared edible fats; animal or vegetable waxes) }\end{array}$ & 7 & 4 & 3 & 1 & 2 \\
\hline Manufacturing & 93 & 96 & 97 & 99 & 98 \\
\hline Prepared foodstuffs; beverages, spirits and vinegar; tobacco & 0 & 1 & 0 & 0 & 1 \\
\hline Mineral products & 17 & 13 & 41 & 72 & 53 \\
\hline Products of the chemical or allied industries & 10 & 10 & 9 & 4 & 7 \\
\hline Wood and articles of wood; & 3 & 5 & 5 & 5 & 9 \\
\hline Textiles and textile articles & 6 & 9 & 6 & 3 & 5 \\
\hline Base metals and articles of base metal & 30 & 26 & 4 & 2 & 4 \\
\hline The manufacture of skilled-labour-intensive products* & 16 & 22 & 21 & 7 & 11 \\
\hline Other & 10 & 10 & 9 & 4 & 8 \\
\hline
\end{tabular}

* Machinery and mechanical appliances; electrical equipment; Vehicles, aircraft, vessels and associated transport equipment; Optical, photographic, cinematographic, measuring, checking, precision, medical or surgical instruments and apparatus; clocks and watches; musical instruments

Source: The Customs Department under the Ministry of Finance of the Republic of Lithuania 


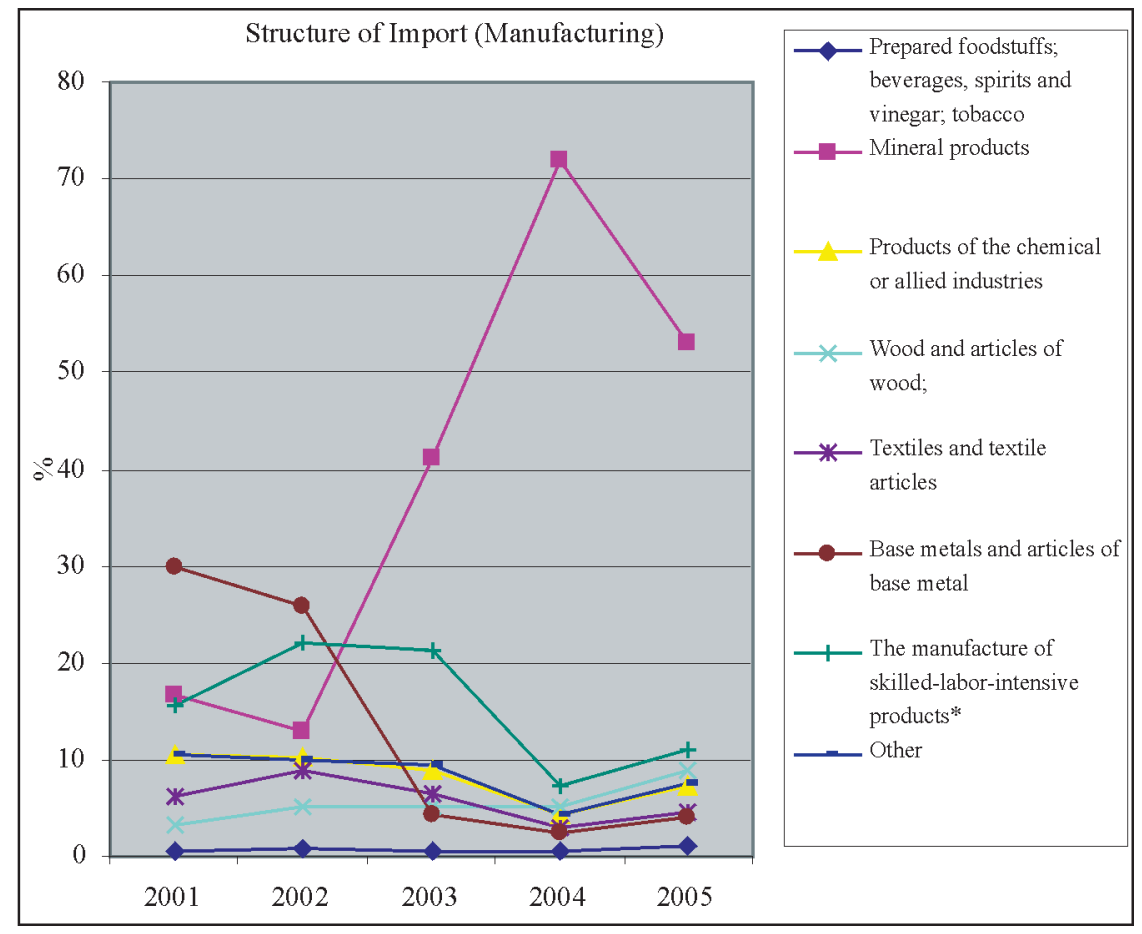

Fig 9. Structure of Imports (Manufacturing)

bor-intensive products has taken the second place in the structure of imports. However, gradual increase of the share of those products since the year 2001 was followed by a decrease in 2004. After accession no visible increase in import of any kinds of products has been recorded.

\section{Conclusions}

The rise of exports to Belarus was gradual throughout the years 2001-2005. Imports from Belarus grew significantly during the pre-accession year (128\%), later dropped. Data on Lithuanian-Belarus trade by product groups indicates that the recorded growth of imports was achieved mainly on account of mineral products (297\%), wood and articles of wood (123\%).

Absolute Lithuanian-Byelorussian trade data indicating volumes of goods traded does not provide actual tendencies if growth of Lithuania's GDP is not being taken into account. The clear rationale lies behind: if trade is developing its share or relative weight in GDP grows as well, and vice versa, respectively. Judging from the recent statistical data Lithuania's GDP has been growing since 2001. Exports to Belarus growing in absolute figures decreased slightly after accession but later the gradual growth recovered. Imports, expressed in terms relative to GDP replicated the already traced tendencies. We can conclude that accession impacted import from Belarus rather significantly.
The fact that change of relative weights of exports to Belarus did not appear in data of export to Belarus, estimated as a share of GDP, leads us to the following corollary. Lithuanian export expanded but it shifted to other, most likely, European countries. Relative decrease of exports to Belarus was neutralized by general expansion of exports (compared to GDP growth). As a result, absolute volume of exports to Belarus increased but, in principal, export to Belarus started gradually to lose its economic importance.

Notably the absolute growth of exports was achieved mainly in textiles and textile articles (55\%), which are considered to be unskilled-labor-intensive products. Export of skilled-labor-intensive products increased by $51 \%$ respectively. Interpreting these tendencies, we need to remember, that in 2004 in the structure of Lithuanian export to Belarus skilled-labor-intensive products comprised $38 \%$. In 2005 the share of skilled-labor-intensive products in LithuanianByelorussian export increased by $47 \%$, while textile articles comprised only a minor share of exports. Hence, we can conclude that Lithuania is increasingly exporting skilled-labor-intensive products to Belarus, which, in their turn, prevail in export structure.

In 2004 in the structure of imports from Belarus mineral products $(72 \%)$ dominated with a minor share of other product groups. However, the change of trade regime diminished the imports of mineral products (to $53 \%$ ). 
So, to sum up, Lithuania's membership in the EU has had its impact on the bilateral trade with Belarus. The analysis by economy sectors allows concluding that exports of skilled-labor-intensive products increasingly dominate, while export of agricultural products is seen as minor and rather unimportant.

The major impact of new trade regime was observed in imports from Belarus. Growth of Lithuanian economy and the rise of domestic consumption caused a sharp increase in mineral products import before the year 2004. However the adoption of the EU trade policy has dramatically decreased imports of this product group after 1 May 2004.

\section{References}

Balance of Payments of the Republic of Lithuania of 2005.

HAMILTON, Carl B. (2005) Russia's European economic integration. Escapism and realities. Economic Systems, 29 (3), September: 294-306.

SALINAS, Gonzalo; AKSOY, Ataman (2006) Growth before and after trade liberalization. World Bank Policy Research Working Paper 4062, November.

TARR, David G.; NAVARETTI, Giorgio Barba. (2005) Introduction and Summary to Handbook of Trade Policy and WTO Accession for Development in Russia and the CIS. World Bank Policy Research Working Paper 3726, October.

The Customs Department under the Ministry of Finance of the Republic of Lithuania.

TVARONAVIČIENĖ, Manuela; TVARONAVIČIUS, Vytautas (2005) Some aspects of Lithuanian foreign trade. Business: Theory and Practice, VI (2), 117-121.

ZGHINI, Andrea. (2005) Evolution of trade patterns in the new EU member states. Economics of Transition, 13(4): 629-658. 